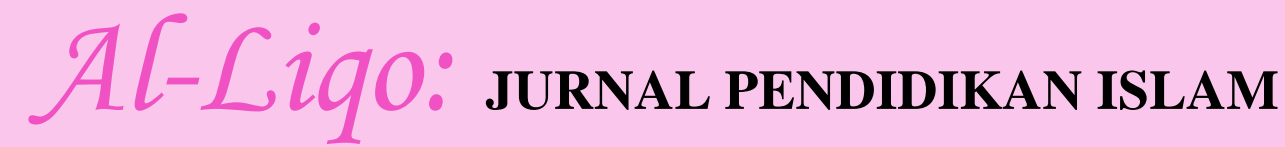 \\ P-ISSN: 2461-033X | E-ISSN: 2715-4556
}

\section{PERAN GURU DALAM PELAKSANAAN BIMBINGAN KONSELING}

\author{
*Sri Mulyati ${ }^{1)}$ Kamaruddin Kamaruddin ${ }^{2)}$ \\ 1) MTSN 2 INHIL, Indragiri Hilir, Riau, Indonesia (sri.mulyti102017@gmail.com) \\ ${ }^{2)}$ STAI Auliaurrasyidin Tembilahan, Indragiri Hilir, Riau, Indonesia (kamaruddin@stai-tbh.ac.id)
}

\begin{abstract}
This study aimed to determine the role of teachers in the implementation of counseling and guidance. The teachers' role in the implementation of counseling must able to involve parties in schools such as students, subject teachers, school principals, and parents so that the counseling program can be carried out properly because there are few things or problems that often arise during the school day. The role of the teacher in this study is the role of a guider, counselor, informant, facilitator, mediator, collaborator, organizer, motivator, director, initiator, transmitter, and evaluator in achieving educational success. This type of research is library research, the method used is qualitative descriptive, Data were analyzed narratively. The result showed that teachers carried out their roles by implementing a continuous process, voluntary nuances, guiding principles for both male and female students, implementing Eastern culture, and implementing effective and efficient implementation.
\end{abstract}

Keywords: Guidance and Counselling, Role, Teacher

\begin{abstract}
Abstrak
Penelitian ini bertujuan untuk mengetahui peran guru dalam pelaksanaan bimbingan konseling. Peran guru dalam pelaksanaan bimbingan konseling harus mampu melibatkan pihak-pihak yang ada di sekolah seperti peserta didik, guru mata pelajaran, kepala sekolah dan orang tua agar terlaksananya program bimbingan konseling dengan baik. Karena banyak hal atau masalahmasalah yang sering kali timbul dalam diri siswa ketika mengikuti proses pembelajaran di sekolah. Peran guru yang dimaksud dalam penelitian ini yaitu peran guru sebagai pembimbing, konselor, informator, fasilitator, mediator, kolaborator, organisator, motivator, director, inisiator, transmitter, dan evaluator dalam mencapai keberhasilan pendidikan di sekolah. Jenis penelitian ini merupakan library research, metode yang digunakan adalah kualitatif dengan desain deskriptif, dan dianalisis dengan kualitatif dalam bentuk narasi. Hasil penelitian adalah guru melaksanakan perannya dalam layanan bimbingan konseling di sekolah dengan menerapkan proses yang kontinu, bernuansa suka rela, membimbing dengan prinsip untuk semua baik siswa laki-laki maupun perempuan, menerapkan budaya ketimuran, dan pelaksanaan yang efektif dan efisien.
\end{abstract}

Kata Kunci: Bimbingan dan Konseling, Peranan, Guru

\section{Cara Mensitasi Artikel:}

Mulyati, S., \& Kamaruddin, K. (2020). Peran Guru dalam Pelaksanaan Bimbingan Konseling. AlLiqo: Jurnal Pendidikan Islam, 5(02), 172-184. https://doi.org/10.46963/alliqo.v5i02.241

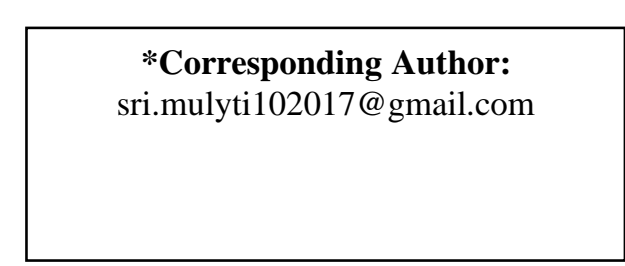

\begin{tabular}{|lc|}
\hline \multicolumn{1}{c|}{ Histori Artikel: } \\
Diterima & $:$ 01/ Des / 2020 \\
Direvisi & $:-$ \\
Diterbitkan & $: 28 / 12 / 2020$ \\
\end{tabular}

DOI: https://doi.org/10.46963/alliqo.v5i02.241 


\section{PENDAHULUAN}

Semua yang terkait dalam proses pendidikan di sekolah tentunya masingmasing mempunyai peran sesuai dengan apa yang dibutuhkan, baik sebagai kepala sekolah, guru, staf atau karyawan, penjaga sekolah dan ibu kantin sekolah sekalipun. Masing-masing peran itu berjalan secara sinergis, saling melengkapi sehingga membentuk suatu sistem yang sangat berkaitan dan harmonis. Dari peran-peran yang ada di sekolah itu, salah satunya peran guru bimbingan konseling sangat penting keberadaannya untuk berlangsungnya kegiatan belajar mengajar dengan baik.

Guru dalam pelaksanaan bimbingan konseling kepada siswa yang bermasalah haruslah berperan menunjukkan jalan yang benar kepada siswa, membimbing siswa dalam menghadapi masalah yang terjadi pada dirinya, membantu siswa dalam menyelesaikan masalah, menentukan sikap hidup yang benar kepada siswa dalam menghadapi permasalahan, mengatur siswa untuk mengakui kesalahannya, mengemudikan bagaimana jalan yang lurus yang harus ditempuh, memimpin siswa dengan sikap yang bijaksana, memberi saran yang baik apa yang harus dilakukan siswa dalam menghadapi permasalahan, dan menuntun siswa untuk siap menghadapi hidup dan permasalahan dengan sabar dan tenang.

Penelitian sebelumnya penulis temukan dalam sebuah jurnal yang berjudul Peran Guru Sebagai Pelaksana Layanan Bimbingan Konseling Dalam Membangun Sikap Disiplin Siswa Di SD Negeri Keputran 2 Yogyakarta Tahun Ajaran 2015/2016, hasil penelitiannya menjelaskan bahwa peran guru sebagai pembimbing, fasilitator, dan kolaborator saja yang sudah dilaksanakan. Sedangkan peran guru sebagai mediator dan informator belum ditemukan atau belum muncul. (Umi Larasati, 2016: 47).

Selanjutnya dalam naskah publikasi yang berjudul Peran Guru Kelas Sebagai Pelaksana Bimbingan Konseling Bagi Peserta Didik Di SD Muhammadiyah 13 Surakarta, hasil penelitiannya menjelaskan peran guru yang dilaksanakan adalah memberikan informasi, selalu membantu siswa dalam 
menyelesaikan permasalahan, dan peran membimbing siswa. (Zia Alfiana Khabibah, 2017: 12-13).

Sebuah artikel dalam jurnal yang berjudul Peran Guru Kelas Pada Pelaksanaan Bimbingan Konseling Dalam Menumbuhkan Sikap Tanggung Jawab Di SD Negeri 1 Pamijen, yang ditulis oleh Dilla Tiara Kusuma Dewi, hasil penelitian menjelaskan bahwa dalam pelaksanaan bimbingan konseling, guru sudah berperan dengan cara memberikan nasehat, motivasi, contoh, koreksi atau penilaian, membimbing, mengingatkan dan memberikan hukuman. (Dilla Tiara Kusuma Dewi, 2019:).

\section{METODE}

Tulisan ini merupakan penelitian pustaka yang memusatkan perhatian pada isu-isu penting seputar penelitian peran guru dan bimbingan konseling. Penelitian ini merupakan penelitian deskriptif dengan menggunakan pendekatan kualitatif. Penelitian deskriptif adalah penelitian yang berusaha mendeskripsikan suatu gejala, peristiwa, kejadian yang terjadi pada saat sekarang. Dengan kata lain, penelitian deskriptif adalah penelitian yang mengambil masalah atau memusatkan perhatian kepada masalah-masalah aktual sebagaimana adanya pada saat penelitian dilaksanakan. (Nana Sudjana dan Ibrahim, 2001: 64). Penelitian ini menggambarkan masalah-masalah yang terjadi pada siswa di sekolah, yang perlu ditangani dengan peran guru di sekolah melalui pelaksanaan bimbingan konseling. 1. Sumber Data

Kajian yang penulis gunakan adalah penelitian perpustakaan murni, penulis akan menggunakan dua sumber, yaitu:

a. Sumber Primer

Sumber data yang bersifat primer adalah buku rujukan awal dan utama dalam penelitian, sumber primer yang penulis gunakan adalah:

1) Dewi, Dilla Tiara Kusuma. (2019). Peran Guru Kelas Pada Pelaksanaan Bimbingan Konseling Dalam Menumbuhkan Sikap Tanggung Jawab Di SD Negeri 1 Pamijen. Jurnal Ilmiah Pendidikan Dasar (2), 115-123, Juli 2019 p-ISSN 2615-1391, e-ISSN 2620=3219@Prodi PGSD Universitas 
Swadaya

Gunung

Jati

file:///C:/Users/TOSHIBA\%20WIN\%208/Downloads/2357-6801-1-

PB.pdf. Diakses pada 2020: 1.40 AM.

2) Fenti Hikmawati. Bimbingan dan Konseling, (2014), Jakarta: PT RajaGrafindo Persada.

3) Heri AS, (2017). Peran Guru BK dalam Penanganan Perilaku Indisipliner Siswa di SMA Inshafuddin Banda Aceh, Banda Aceh, UIN Ar Raniry.

4) Kementerian Pendidikan Dan Kebudayaan Republik Indonesia, (2016). Pedoman Bimbingan Dan Konseling Pada Pendidikan Dasar dan Pendidikan Menengah.

5) Khabibah, Zia Alfiana. (2017). Peran Guru Kelas Sebagai Pelaksana Bimbingan Konseling Bagi Peserta Didik Di SD Muhammadiyah 13 Surakarta.

http://eprints.ums.ac.id/55151/1/11.\%20NASKAH\%20PUBLIKASI.pdf diakses 2020: 1.21 AM.

6) Larasati, Umi. Peran Guru Sebagai Pelaksana Layanan Bimbingan Konseling Dalam Membangun Sikap Disiplin Siswa Di SD Negeri Keputran 2 Yogyakarta Tahun Ajaran 2015/2016. https://media.neliti.com/media/publications/258994-peran-guru-sebagaipelaksana-layananbimb-cc7c0b1a.pdf diakses 2020: 1.01 AM

7) Peraturan Menteri Pendidikan Dan Kebudayaan Republik Indonesia, (2014). Nomor 111 Tentang Bimbingan Konseling Pada Pendidikan Dasar Dan Pendidikan Menengah.

b. Sumber Sekunder

Sumber sekunder adalah hasil pengumpulan yang dilakukan oleh orang lain dengan maksud tertentu dan mempunyai kategori atau klasifikasi menurut keperluan masing-masing dan kegunaan bagi peneliti masingmasing, S. Nasotion (2002: 143) 
Dalam hal ini Sumber data yang bersifat sekunder adalah buku rujukan pendukung dalam penelitian, sumber sekunder yang penulis gunakan adalah:

i. Mulawarman, Pengantar Keterampilan Dasar Konseling bagi Konselor Pendidikan, (Semarang: Universitas Negeri Semarang).

ii. Rifda, Bimbingan Konseling di Sekolah, Lampung: LP2M, 2015.

iii.Sudjana, Nana dan Ibrahim, (2001), Penelitian dan Penilaian Pendidikan, Bandung: Sinar Baru Algesindo.

\section{HASIL DAN PEMBAHASAN}

Sebelum mengkaji lebih dalam tentang peran guru, hendaknya terlebih dahulu peneliti memaparkan tentang apa itu bimbingan, apa itu konseling, dan apa itu bimbingan konseling?

\section{A. Apa Itu Bimbingan ?}

Bimbingan dan Konseling merupakan terjemahan dari "guidance" dan "Counseling" dalam bahasa Inggris. "Guidance" atau akar katanya "guide" bermakna menunjukkan, membimbing, membantu, menentukan, mengatur, mengemudikan, memimpin, memberi saran, ataupun menuntun. Jadi bimbingan dapat diartikan membantu atau menuntun. Namun tidak semua bantuan atau tuntunan merupakan bimbingan. Bantuan yang bermakna hendaknya senantiasa memenuhi serangkaian syarat dan prinsip seperti berikut ini.

1. Bimbingan merupakan suatu proses kontinu, sistematis, berencana, dan terarah kepada satu tujuan.

2. Bimbingan merupakan proses membantu individu.

Membantu bermakna bahwa bimbingan adalah aktivitas yang bernuansa sukarela dan tidak ada unsur paksaan baik dari pihak yang membimbing (konselor) maupun dari pihak yang dibimbing (konseli).

3. Bimbingan adalah bimbingan untuk semua, "guidance for all".

Statemen ini bermakna bahwa bimbingan diberikan kepada setiap individu yang membutuhkan dalam proses perkembangannya, yaitu individu yang 
ada di sekolah maupun luar sekolah, baik laki-laki atau perempuan, anakanak, remaja, dewasa, hingga orang tua.

4. Bahwa bantuan yang diberikan dalam kegiatan bimbingan bertujuan agar individu mampu mengembangkan dirinya secara optimal sesuai dengan potensi yang ada pada dirinya.

5. Sasaran dan fokus bimbingan adalah tercapainya kemandirian individu, yaitu tercapainya perkembangan yang optimal dan dapat menyesuaikan dirinya dengan lingkungan sehingga tercapai kebahagiaan hidupnya.

6. Tujuan yang telah dipaparkan di atas dapat dipaparkan dengan berbagai pendekatan, teknik, dan pendekatan baik secara individual maupun kelompok.

7. Penggunaan berbagai jenis media dalam aktivitas bimbingan hendaknya dilaksanakan dalam suasana asuhan yang formatif, yang dalam budaya ketimuran (Indonesia) suasana ini dikenal dengan istilah Tutwuri Handayani, Ing Madya Mangun Karsa, dan Ingarso Sung Tulodo.

8. Untuk melaksanakan aktivitas bimbingan yang efektif dan efisien hendaknya dilakukan oleh personil-personil yang memiliki keahlian, keterampilan, dan pengalaman khusus dalam bidang bimbingan. (Rifda, 2015: 1)

Tohari Musnamar mengutip Athur Jones mendefinisikan bimbingan sebagai pertolongan yang diberikan oleh seseorang kepada orang lain dalam hal membuat pilihan, penyesuaian diri dan pemecahan berbagai problem. Tujuannya agar yang dibantu tersebut dapat tambah dalam kemandirian dan kemampuan bertanggung jawab bagi dirinya sendiri.

Sedangkan Shertzer dan Stone (1971) yang dikutip Yusuf dan Nurhisan mengartikan bimbingan sebagai "process of helping an individual to understand himself and his world", yakni sebagai proses pemberian bantuan kepada individu agar mampu memahami diri dan lingkungannya. (Rifda, 2015: 4).

Menurut Umar dan Sartono dalam bukunya Bimbingan dan Penyuluhan, mengemukakan bahwa Bimbingan adalah bantuan yang diberikan kepada individu agar dengan potensi yang dimiliki mampu mengembangkan diri secara optimal dengan 
jalan memahami diri, memahami lingkungan, mengatasi hambatan dengan menentukan rencana masa depan yang lebih baik.

Untuk memperoleh pengertian yang lebih jelas, di bawah ini dikutip beberapa definisi:

1) Menurut Jear Book of Education (1995), bimbingan adalah suatu proses membantu individu melalui usahanya sendiri untuk menemukan dan mengembangkan kemampuannya agar memperoleh kebahagiaan pribadi dan kemanfaaatan sosial.

2) Menurut Crow \& Crow, bimbingan dapat diartikan sebagai bantuan yang diberikan oleh seseorang baik pria maupun wanita yang memiliki pribadi yang baik dan pendidikan yang memadai kepada seorang individu setiap usia untuk menolongnya mengemudikan kegiatan-kegiatan hidupnya sendiri, mengembangkan arah pandangannya sendiri, membuat pilihannya sendiri dan memikul bebannya sendiri.

3) Menurut Stopps, yang dikutip oleh Umar-Santoso bimbingan adalah suatu proses yang terus menerus dalam membantu perkembangan individu untuk mencapai kemampuannya secara maksimal dalam mengarahkan manfaat yang sebesar-besarnya, baik bagi dirinya maupun bagi masyarakat. (UmarSantoso, 2012: 9).

Dari uraian-uraian di atas dapat disimpulkan mengenai pengertian bimbingan, yaitu proses pemberian bantuan dari seorang pembimbing kepada individu yang membutuhkannya dalam rangka mengembangkan seluruh potensi yang dimiliki secara optimal dengan memanfaatkan berbagai media dan teknik bimbingan dalam suasana yang bernuansa normatif agar individu mencapai kemandiriannya dan bermanfaat bagi diri sendiri, lingkungan, dan mencapai kebahagiaan dunia dan akhirat.

\section{B. Apa Itu Konseling.}

Konseling menurut Prayitno, istilah konseling secara etimologis berasal dari bahasa latin "consilen" yang berarti "dengan atau bersama", yang dirangkai dengan "menerima" "memahami”. Sedangkan Hornby (1958) yang dikutip Hallen mengemukakan bahwa istilah konseling berasal dari bahasa 
Inggris "to counsel" yang secara etimologis berarti "to give advice" yang berarti memberi saran dan nasehat. (Rifda, 2015: 6).

Istilah konseling selalu mengikuti istilah bimbingan hal ini disebabkan keintegralan kegiatan bimbingan dan konseling yang dalam sejumlah literatur dipandang sebaga "jantung hatinya program bimbingan" (counseling is the heart of guidance), juga merupakan salah satu teknik bimbingan dalam aktivitas layanan bimbingan dan konseling diantara sejumlah teknik lainnya.

Menurut Sunaryo Kartadinata (2010) konseling merupakan perjumpaan psikososio kultural antara konselor dengan konseli (individu yang memperoleh layanan), dan sebagai layanan ahli konseling dilaksanakan dengan dilandasi motif altruistik dan empatik dengan selalu mempertimbangkan dampak jangka panjang dari layanan yang diberikan kepada konseli. Dengan sifat layanan seperti itu, maka seorang konselor dapat disebut sebagai safe practicioner.

Pepinsley yang dikutip Prayitno menyatakan bahwa konseling : Interaksi yang terjadi antara dua orang individu yang disebut konselor dan klien, terjadi suasana yang profesional dan dilakukan sebagai alat memudahkan perubahanperubahan dalam tingkah laku klien.

Rogers (1942) mengemukakan sebagai berikut : Conseling is series direct contact with the individual which ains to after him assistence in changing his attitude and behavior. Makna yang diambil dari definisi di atas adalah konseling merupakan serangkaian hubungan langsung dengan individu yang bertujuan untuk membantu dia mengubah sikap dan perilakunya. (Rifda, 2015: $7)$.

Menurut Mulawarman dalam buku ajarnya mengemukakan bahwa Konseling adalah suatu layanan profesional yang dilakukan oleh para konselor yang terlatih secara profesional. (Mulawarman, : 5).

Menurut Pietrofesa, Leonarddan Hoose (1978) dalam Mappiare menyatakan bahwa definisi konseling dapat digambarkan konseling adalah suatu proses dimana ada seseorang yang dipersiapkan secara profesional untuk membantu orang lain dalam memahami diri, pembuatan keputusan dan 
memecahkan masalah. Selain itu konseling adalah pertemuan "dari hati ke hati" antar manusia yang hasilnya sangat bergantung pada kualitas hubungan.

C.H. Patterson (1959) dalam Abimanyu dan Manrihu, mengemukakan bahwa konseling adalah proses yang melibatkan hubungan antar pribadi antara seseorang terapis dengan satu atau lebih klien dimana terapis menggunakan metode-metode psikologis atas dasar pengetahuan sistematik tentang kepribadian manusia dalam upaya meningkatkan kesehatan mental klien.(Mulawarman: 5).

\section{Apa Itu Bimbingan Konseling?}

Bimbingan Konseling merupakan proses bantuan atau pertolongan yang diberikan oleh pembimbing (konselor) kepada individu (konseli) melalui pertemuan tatap muka atau hubungan timbal balik antara keduanya, agar konseli memiliki kemampuan dalam menemukan masalahnya serta mampu memecahkan masalahnya sendiri.

Bimbingan konseling merupakan proses interaksi antara konselor yakni guru di sekolah dengan konseli yaitu siswa baik laki-laki maupun perempuan yang punya masalah dalam proses pembelajaran di sekolah baik pelaksanaannya dilakukan secara langsung maupun tidak langsung dalam rangka untuk membantu siswa memecahkan masalah yang terjadi pada diri individunya. (Buku Panduan Bimbingan Konseling, 2016: 3-4).

Bimbingan konseling dapat juga diartikan sebagai upaya yang dilakukan guru di sekolah secara sistematis bersama pihak-pihak yang ada di sekolah baik kepala sekolah, semua guru-guru, staf akademik, dan orang tua siswa, terhadap masalah-masalah yang benar-benar terjadi pada siswa dalam proses belajar mengajar, yang penanganan masalahnya sesuai dengan logika dan pelaksanaannya berkesinambungan sampai masalah sudah dapat teratasi dengan baik dengan tujuan untuk mencapai kemandirian dalam kehidupan siswa. (Permendikbud Nomor 111, 2014: 2). 


\section{Peran Guru}

Dalam kedudukan sebagai personel pelaksana proses pembelajaran di sekolah guru memiliki posisi strategis. Dibanding dengan guru pembimbing atau konselor, misal: guru lebih sering berinteraksi dengan siswa secara langsung. Apabila dirinci ada beberapa peranan yang dapat dilakukan oleh seorang guru, ketika ia diminta mengambil bagian dalam penyelenggaraan program bimbingan dan konseling di sekolah.

1) Guru sebagai Informatory

Guru dalam kinerja dapat berperan sebagai informator, berkaitan dengan tugasnya membantu guru pembimbing atau konselor dalam memasyarakatkan layanan bimbingan dan konseling kepada siswa pada umumnya.

2) Guru sebagai Fasilitator

Guru berperan sebagai fasilitator terutama ketika dilangsungkan layanan pembelajaran baik itu yang bersifat preventif ataupun kuratif. Dibandingkan guru pembimbing, guru lebih memahami tentang keterampilan belajar yang perlu dikuasai siswa pada mata pelajaran yang diajarkan.

3) Guru sebagai Mediator

Guru dapat berperan sebagai mediator antara siswa dengan guru pembimbing. Misalnya saat diminta untuk melakukan kegiatan identifikasi siswa yang memerlukan bimbingan dan pengalihtanganan siswa yang memerlukan bimbingan dan konseling kepada guru pembimbing atau konselor sekolah.

4) Guru sebagai Kolaborator

Sebagai mitra seprofesi yakni sama-sama sebagai tenaga pendidik di sekolah, guru dapat berperan sebagai kolaborator. Konselor di sekolah misal dalam penyelenggaraan berbagai jenis layanan orientasi informasi.

Secara operasional pelaksana utama layanan bimbingan dan konselor sekolah di bawah koordinasi seorang koordinator bimbingan dan konseling. Penyelenggaraan melibatkan personel sekolah lainnya agar lebih berperan 
sesuai batas-batas kewenangan dan tanggung jawab. Personel mencakup: kepala sekolah, wakil kepala sekolah, koordinator bimbingan dan konselong, guru pembimbing, guru wali kelas, dan staf administrasi. (Fenti Hikmawati, 2014: 22).

Heri AS, Sardiman menyatakan bahwa ada sembilan peran guru dalam kegiatan bimbingan konseling, yaitu :

1) Informator, guru diharapkan sebagai pelaksana cara mengajar informatif, laboratorium, studi lapangan, dan sumber informasi kegiatan akademik maupun umum.

2) Organisator, guru sebagai pengelola kegiatan akademik, silabus, jadwal pelajaran dan lain-lain.

3) Motivator, guru harus mampu merangsang dan memberikan dorongan serta reinforcement untuk mendinamisasikan potensi siswa, menumbuhkan swadaya (aktivitas) dan daya cipta (kreativitas) sehingga akan terjadi dinamika di dalam proses belajar mengajar.

4) Director, guru harus dapat membimbing dan mengarahkan kegiatan belajar siswa sesuai dengan tujuan yang dicita-citakan.

5) Inisiator, guru sebagai pencetus ide dalam proses belajar mengajar.

6) Transmitter, guru bertindak selaku penyebar kebijaksanaan dalam pendidikan dan pengetahuan.

7) Fasilitator, guru akan memberikan fasilitas dan kemudahan dalam proses belajar mengajar.

8) Mediator, guru sebagai penengah dalam kegiatan belajar siswa.

9) Evaluator, guru mempunyai otoritas untuk menilai prestasi anak didik dalam bidang akademik maupun tingkah laku sosialnya, sehingga dapat menentukan bagaimana anak didiknya berhasil atau tidak. (Heri AS, 2017: $33)$.

Dari dua pendapat peran guru BK di atas, dapat disimpulkan bahwa peran guru BK adalah sebagai informator, organisator, motivator, director, inisiator, transmitter, fasilitator, mediator, dan evaluator. 


\section{KESIMPULAN}

Peran guru dalam pelaksanaan bimbingan konseling sangat urgen dalam rangka tercapainya tujuan pembelajaran dengan baik. Peran guru dalam memberikan bimbingan konseling kepada siswa seperti siswa yang merasa ada kesulitan dalam belajarnya, sehingga dengan perannya guru perlu mencari sumber-sumber kesulitan belajar yang dialami siswa. Guru dengan perannya dalam melaksanakan bimbingan konseling memberikan bantuan kepada siswa sesuai dengan batas kemampuan yang dimiliki guru dan batas kewenangannya dalam memecahkan masalah pribadi siswa yang dipandang guru tepat untuk menangani permasalahan tersebut.

\section{REFERENSI}

Dewi, D. T. K. (2019). Peran Guru Kelas Pada Pelaksanaan Bimbingan Konseling Dalam Menumbuhkan Sikap Tanggung Jawab Di SD Negeri 1 Pamijen. Jurnal Ilmiah Pendidikan Dasar 2(2), 115-123. http://dx.doi.org/10.33603/.v2i2.2357

Fenti Hikmawati. Bimbingan dan Konseling. (2014). Jakarta: PT RajaGrafindo Persada.

Heri, A. S. (2017). Peran Guru BK dalam Penanganan Perilaku Indisipliner Siswa di SMA Inshafuddin Banda Aceh, Banda Aceh, UIN Ar Raniry.

Kementerian Pendidikan Dan Kebudayaan Republik Indonesia. (2016). Pedoman Bimbingan Dan Konseling Pada Pendidikan Dasar dan Pendidikan Menengah.

Khabibah, Z. A. (2017). Peran Guru Kelas Sebagai Pelaksana Bimbingan Konseling Bagi Peserta Didik Di SD Muhammadiyah 13 Surakarta. http://eprints.ums.ac.id/55151/1/11.\%20NASKAH\%20PUBLIKASI.pdf diakses 2020: 1.21 AM.

Larasati, U., Sindhuredja, F. X. (2016). Peran Guru Sebagai Pelaksana Layanan Bimbingan Konseling Dalam Membangun Sikap Disiplin Siswa Di SD Negeri Keputran 2 Yogyakarta Tahun Ajaran 2015/2016. TRIHAYU: Jurnal Pendidikan Ke-SD-an, 3(1), 43-47. http://dx.doi.org/10.30738/trihayu.v3i1.815

Mulawarman, Pengantar Keterampilan Dasar Konseling bagi Konselor Pendidikan, Semarang: Universitas Negeri Semarang. 
Peraturan Menteri Pendidikan Dan Kebudayaan Republik Indonesia. (2014). Nomor 111 Tentang Bimbingan Konseling Pada Pendidikan Dasar Dan Pendidikan Menengah.

Rifda. (2015). Bimbingan dan Konseling di Sekolah, Lampung: LP2M.

Sudjana., Nana., \& Ibrahim. (2001). Penelitian dan Penilaian Pendidikan, Bandung: Sinar Baru Algesindo.

Umar, S. (2020). Bimbingan dan Penyuluhan. (2012). Bandung: CV Pustaka Setia. 